\section{Need Analysis for Choosing English Teaching Concepts at IPDN}

\author{
1 Layla Kurniawati \\ 2 Edi Wahyono \\ 1 Institut Pemerintahan Dalam Negeri (IPDN), Indonesia \\ 2 Universitas Cokroaminoto Palopo, Indonesia
}

\begin{abstract}
English is a subject that given in the three curriculum systems at IPDN has not been implemented maximally. The three existing curriculum systems provide almost the same material and there are not clear and obvious differences. In order to improve the teaching conditions, need analysis is used to find and determine what English learning materials are appropriate and suitable for teaching and learning at IPDN. A descriptive qualitative approach through document study, interview, and observation was used in this research. From the analysis, teaching English must be developed with the collaborative approach among education personnel (lecturers, trainers, fellows) and students in the three curriculum systems at IPDN. English teaching emphasizes reading skills, where teaching reading focuses on English for Specific Purposes of Government administration as core knowledge.
\end{abstract}

\section{Keywords}

need analysis

teaching concept

collaborative approach

\section{Ethical Lingua}

Vol. 7, No. 2, 2020

ISSN 2355-3448 (Print)

ISSN 2540-9190 (Online)

Corresponding Email

Layla Kurniawati

laylakurniawati@ipdn.ac.id

Article's History

Submitted 23 August 2020

Revised 7 September 2020

Revised 25 September 2020

Accepted 25 September 2020

DOI

10.30605/25409190.211

Copyright $\odot 2020$

The Author(s)

This article is licensed under CC BY-NC-SA 4.0 License

\section{(cc) EY-NC-SA}




\section{Need Analysis for Choosing English Teaching Concepts at IPDN}

The Local Government Institute of Home Affairs (IPDN) is a boarding higher education under the Ministry of Home Affairs which has a specific curriculum (teaching, training, and parenting system of curriculum) that is different from other higher education in Indonesia. Besides the differences of three system of curriculum, IPDN also has tasks for educating the candidate of Civil Servants who will be deployed in all Indonesia Local and Central government in Indonesia.

English is also the course that belongs to these three specific curriculums. As a theoretical concept English belongs to teaching curriculum with two credits for one semester. Meanwhile for developing the four English skills, English is accommodated at training curriculum. At parenting curriculum system, English is given in the form of affective spirit by asking the students for applying English every Friday.

Based on the observation, the documents of English teaching and learning show that the curriculum implementation of English teaching at the three curriculum systems has some problems: a). Teaching English at training and teaching curriculum seems to be similar in the form of activities, the materials that emphasize on developing English grammar; b). Teaching English tends to be teacher centered, and it does not provide opportunities for students to explore and develop their English skills actively through speaking; $c$ ). The documents show that the examination tends to be grammar, vocabulary and each lecturers and trainers gives different examination exercises. d). The implementation of English teaching at parenting system curriculum does not implement optimally. Based on the observation fellows and students do no use English for Friday English day. It is only written curriculum document without any real implementation. In relation with the identification of the problems, the researcher wants to find the suitable concept of IPDN English teaching learning by using needs analysis.

\section{Method}

According to Heigham \& Croker (2011), qualitative research is a special term which is used as a compound for developing method of research. The research methodology has source number of various discipline knowledge, such as philosophy, anthropology, sociology, and recently it is used in almost field of social science exploration involve applied linguistics. Meanwhile, Creswell (2009) said qualitative research as inspection and comprehension the definition of single or class for assigning of human and social issues.

The research method is descriptive qualitative. Researcher collected various sources of data through documents (e.g. teaching schedules; note of English session for each sessions, etc). Doing interview for IPDN educational staffs such as lecturers, trainers and caregivers and also interview for students. The researcher also made direct observations in the field related to the existing process of teaching English at IPDN. Furthermore, the data collection techniques, the researchers also observed various internal and external factors of IPDN both in terms of strengths, weaknesses, opportunities and threats belongs to IPDN. After obtaining the data, the researcher grouped and categorized the data based the need of data research and analyzed them to find selected strategies of English teaching concept for boarding higher education at IPDN. For maintaining data validity, researcher used triangulation. 


\section{Results}

Researcher collected all data document related to English teaching and learning in all three curriculum systems at IPDN, such as document of lectures, trainers educational background. The results are presented in table 1 below:

Table 1. Educational background of IPDN English Lecturers and Trainers

\begin{tabular}{|c|c|c|c|c|c|c|}
\hline \multirow{2}{*}{ No } & \multirow{2}{*}{ Name } & \multirow{2}{*}{ Position } & \multicolumn{3}{|c|}{ Education } & \multirow{2}{*}{$\begin{array}{l}\text { Other } \\
\text { Information }\end{array}$} \\
\hline & & & s1/Bachelors & S2/Masters & S3/Doctorate & \\
\hline 1. & MGS & Lecturer & English Edu & Administration & - & Functional \\
\hline 2. & DIK, & Lecturer & English Edu & Social & - & Functional \\
\hline 3. & IDS & Trainer & English Edu & $\begin{array}{l}\text { Magister } \\
\text { Management }\end{array}$ & - & Staff \\
\hline 4. & UBS & Lecturer & English Edu & Administration & - & Functional \\
\hline 5. & LK & Lecturer & English Edu & English Edu & $\begin{array}{l}\text { Curriculum } \\
\text { Development }\end{array}$ & Functional \\
\hline 6. & TK & Lecturer & English Edu & Administration & - & Functional \\
\hline 7. & ANR & Lecturer & Government & Public Policy & - & Functional \\
\hline 8. & WA & Lecturer & Government & Public Policy & - & Functional \\
\hline 9. & MTR & Staff & English Edu & Linguistic & - & Staff \\
\hline 10. & JDA & Lecturer & Economy & Economy & - & Functional \\
\hline 11. & STM & Lecturer & Economy & English Edu & $\begin{array}{l}\text { Curriculum } \\
\text { Development }\end{array}$ & Functional \\
\hline 12 & RTH & Lecturer & $\begin{array}{l}\text { Technology } \\
\text { Information }\end{array}$ & Planology & - & Functional \\
\hline
\end{tabular}

Based on table one, it appears eight or $66.6 \%$ IPDN English Language lecturers have English Educational background. There are still 4 or $33.4 \%$ of lecturers who do not have English background. Beside the educational background data, the researcher also presents English Material Data for each learning session according to the lecturer's or Trainer's attendant card.

Table 2. English Lesson Materials

\begin{tabular}{|c|c|c|c|c|c|c|c|c|}
\hline & A & B & C & D & $E$ & $F$ & G & H \\
\hline 1. & $\begin{array}{l}\text { Intro. \& } \\
\text { Writing }\end{array}$ & $\begin{array}{l}\text { Introduc- } \\
\text { tion }\end{array}$ & Introduction. & $\begin{array}{l}\text { Introduc- } \\
\text { tion }\end{array}$ & $\begin{array}{l}\text { Introduction, } \\
\text { lists of } \\
\text { lesson in } 1 \\
\text { semester }\end{array}$ & $\begin{array}{l}\text { Introductio } \\
\mathrm{n}\end{array}$ & Task & Introduction \\
\hline 2. & $\begin{array}{l}\text { Speaking + } \\
\text { Simple } \\
\text { Prest. } \\
\text { Tense }\end{array}$ & $\begin{array}{l}\text { Question } \\
\text { Taq }\end{array}$ & $\begin{array}{l}\text { State In } \\
\text { dependent } \\
\text { Clause, there } \\
\& \text { It (1 - } 5 \\
\text { exercises) }\end{array}$ & $\begin{array}{l}\text { Translation } \\
\text { tasks }\end{array}$ & $\begin{array}{l}\text { Read text, } \\
\text { Introduction } \\
\text { of Pancasila }\end{array}$ & Interview & Tasks & $\begin{array}{l}\text { Reading\& } \\
\text { Discussion } \\
\text { (Unemploy } \\
\text { ment) }\end{array}$ \\
\hline 3. & Our Capital & Vocab. & $\begin{array}{l}\text { Executive } \\
\text { Branch }\end{array}$ & $\begin{array}{l}\text { Combat } \\
\text { Conversati } \\
\text { on }\end{array}$ & $\begin{array}{l}\text { Read text } \\
\text { (RT) } \\
\text { Pancasila }\end{array}$ & $\begin{array}{l}\text { Prepositio } \\
\text { n }\end{array}$ & $\begin{array}{l}\text { Introductio } \\
\text { n \& } \\
\text { learning } \\
\text { Contract }\end{array}$ & $\begin{array}{l}\text { R \& D } \\
\text { "Higher } \\
\text { education". }\end{array}$ \\
\hline
\end{tabular}




\begin{tabular}{|c|c|c|c|c|c|c|c|c|}
\hline & A & B & C & D & $E$ & $F$ & G & H \\
\hline 4. & $\begin{array}{l}\text { Dictation \& } \\
\text { Synonyms }\end{array}$ & Idiom & $\begin{array}{l}\text { Listening } \\
\text { \&Grammar }\end{array}$ & $\begin{array}{l}\text { Passive } \\
\text { Form }\end{array}$ & $\begin{array}{l}\text { RT History } \\
\text { of Indonesia }\end{array}$ & $\begin{array}{l}\text { Curriculum } \\
\text { Vitae }\end{array}$ & $\begin{array}{l}\text { Part of } \\
\text { Speech }\end{array}$ & $\begin{array}{l}\text { R\&D } \\
\text { "Problem } \\
\text { Solving" }\end{array}$ \\
\hline 5. & Reading & Listening & Story Telling & $\begin{array}{l}\text { Synonym/ } \\
\text { Antonym }\end{array}$ & & $\begin{array}{l}\text { Pronunciat } \\
\text { ion }\end{array}$ & $\begin{array}{l}\text { Passive \& } \\
\text { Active; } \\
\text { Direct \& } \\
\text { indirect }\end{array}$ & $\begin{array}{l}\text { R \&D } \\
\text { "Decision } \\
\text { Making" }\end{array}$ \\
\hline 6. & Writing & Vocab. & $\begin{array}{l}\text { Mengerjakan } \\
\text { Tugas }\end{array}$ & $\begin{array}{l}\text { Short } \\
\text { Conversati } \\
\text { on }\end{array}$ & & Practices & $\begin{array}{l}\text { Presentati } \\
\text { on Group } \\
2\end{array}$ & $\begin{array}{l}\text { R \& D } \\
\text { "Kinship } \\
\text { the Family" }\end{array}$ \\
\hline 7. & Portfolio & Tenses & $\begin{array}{l}\text { Mengerjakan } \\
\text { Tugas }\end{array}$ & $\begin{array}{l}\text { Vocab Test } \\
300\end{array}$ & & Grammar & $\begin{array}{l}\text { Presentati } \\
\text { on Group } \\
2\end{array}$ & $\begin{array}{l}\text { R \& D "Civil } \\
\text { Education" }\end{array}$ \\
\hline 8. & $\begin{array}{l}\text { Vocab. } \\
\text { How to } \\
\text { make } \\
\text { Chicken } \\
\text { Soup }\end{array}$ & Speaking & $\begin{array}{l}\text { Legislative } \\
\text { Branch, } \\
\text { Suffixes \& } \\
\text { Prefixes. }\end{array}$ & Grammar & & Grammar & - & $\begin{array}{l}\text { R \& D } \\
\text { "Conflict } \\
\text { Resolution" }\end{array}$ \\
\hline \multirow[t]{3}{*}{9.} & Mid Term & Mid Term & Mid & Mid & Mid Term & Mid Term & Mid Term & Mid Term \\
\hline & Test & Test & Term & Term & Test & Test & Test & Test \\
\hline & & & Test & Test & & & & \\
\hline 10. & Speaking & Letter & $\begin{array}{l}\text { Listening: } \\
\text { The } \\
\text { weekends; } \\
\text { What does } \\
\text { he looks like; } \\
\text { Facts \& } \\
\text { Figures. }\end{array}$ & Structure & & Sentences & - & $\begin{array}{l}\text { R \& D “On } \\
\text { Gender" }\end{array}$ \\
\hline 11. & Speaking & $\begin{array}{l}\text { Write \& } \\
\text { Explain }\end{array}$ & $\begin{array}{l}\text { Check \& } \\
\text { Balances } \\
\text { Reading } \\
\text { Skills }\end{array}$ & Translation & & $\begin{array}{l}\text { Present } \\
\text { Participle }\end{array}$ & & $\begin{array}{l}\text { R \& D “On } \\
\text { Gender" }\end{array}$ \\
\hline 12. & & & $\begin{array}{l}\text { Crossword } \\
\text { Puzzle }\end{array}$ & Grammar & & $\begin{array}{l}\text { Present } \\
\text { Perfect }\end{array}$ & & $\begin{array}{l}\text { R\&D "On } \\
\text { Leadership } \\
\text { 1" }\end{array}$ \\
\hline 13. & & & Grammar & Review & & $\begin{array}{l}\text { Adv, Adj, } \\
\text { Noun }\end{array}$ & & $\begin{array}{l}\text { R\&D "On } \\
\text { Leadership } \\
\text { 2" }\end{array}$ \\
\hline 14. & & & Review & & & $\begin{array}{l}\text { Present } \\
\text { Perfect } \\
\text { Tense }\end{array}$ & & \\
\hline
\end{tabular}

Table 2 shows the distribution of English teaching materials in each class and each lecturer are different and depend on each lecturer's interest. The English teaching materials focus on teaching grammar and vocabulary. It is like the materials at middle and final Examination of English. Each lecturer also has a different examination material, therefore each class in the same level will have different examination exercises depend on their lecturers. 
Table 3. English Middle Test Examination

\begin{tabular}{|c|c|c|c|}
\hline $\begin{array}{l}\text { Names of } \\
\text { Lectures }\end{array}$ & Duration & Instrument & Instructions \\
\hline \multirow[t]{5}{*}{ A } & 90 minutes & Test Exercises & 1. Translation \\
\hline & & & 2. Question Answer of Tranlating; \\
\hline & & & 3. Completing the sentence \\
\hline & & & 4. Choose the appropriate word; \\
\hline & & & 5. Choose simple to complex sentences \\
\hline \multirow[t]{3}{*}{ B } & 90 minutes & Test Exercises & $\begin{array}{l}\text { 1. Fill the gaps in the text by choosing the best answer } \\
\text { (multiple choice) (kaitannya dg grammar); }\end{array}$ \\
\hline & & & $\begin{array}{l}\text { 2. complete the word below by using the verb be+ adj, } \\
\text { noun, preposition and progressive verb. Pola sentence } \\
\text { pattern dan ss diminta membuat sesuai pola yg } \\
\text { disediakan; }\end{array}$ \\
\hline & & & 3. Answer the questions below with the correct answer; \\
\hline \multirow[t]{4}{*}{ C } & 90 minutes & Test Exercises & $\begin{array}{l}\text { 1. Are the following words noun or adj. The suffixes will tell } \\
\text { you on the lines, write noun or adj; }\end{array}$ \\
\hline & & & 2. Match the words with their meaning; \\
\hline & & & 3. Tell about your region profile \\
\hline & & & $\begin{array}{l}\text { 4. Fill the missing gaps in the sentence below by choosing } \\
\text { the words below (mengisi kalimat yang belum lengkap } \\
\text { dengan pilihan kata yg telah disediakan) }\end{array}$ \\
\hline \multirow[t]{5}{*}{$\mathrm{D}$} & 90 minutes & Test Exercises & $\begin{array}{l}\text { 1. Make the following sentences (1) Interogative; (2) } \\
\text { Negative }\end{array}$ \\
\hline & & & 2. Put the verbs in parentheses into the correct tense; \\
\hline & & & 3. Put the verbs in parentheses into the correct tense; \\
\hline & & & 4. What do the words below stand for? \\
\hline & & & 5. Make sentences from the words below. \\
\hline \multirow[t]{3}{*}{$\mathrm{E}$} & 90 minutes & Test Exercises & $\begin{array}{l}\text { 1. Mention several things that you should do and should not } \\
\text { do when you introduce yourself? }\end{array}$ \\
\hline & & & 2. Fill the blank from the words bellow. \\
\hline & & & $\begin{array}{l}\text { 3. Complete the sentences by using past simple. Put the } \\
\text { verb into the correct form, positive or negative. }\end{array}$ \\
\hline \multirow[t]{5}{*}{$\mathrm{F}$} & 90 minutes & Test Exercises & 1. Read the following paragraph by hearth; \\
\hline & & & $\begin{array}{l}\text { 2. Use the words below to write questions. Then answer the } \\
\text { questions. }\end{array}$ \\
\hline & & & 3. Put three or four words into the following sentences. \\
\hline & & & 4. Put in the blanks with the correct words. \\
\hline & & & 5. Fill in the blanks with the correct derivatives. \\
\hline \multirow[t]{3}{*}{ G } & 90 minutes & Test Exercises & 1.Use tenses correctly: \\
\hline & & & $\begin{array}{l}\text { Fill in the blanks in the sentence below, using the appropriate } \\
\text { tense form- simple past, or pas perfect of the verb. (use } \\
\text { the hints given within brackets); }\end{array}$ \\
\hline & & & Put the verb in the present continuous or present simple \\
\hline
\end{tabular}


Rewrite the following passages in correct English. Warning:

some instances of the continuous tense here are incorrect, others are incorrect. You have to correct which is which!)

2. Read the text carefully and answer the questions given below...

3. Please Choose one of the topic below. Write an essay at least 100 words.

4. Translate the following passage into Indonesia.

The tendency of giving midterm exam questions as presented in table 3 shows the tendency of giving questions among the lecturers are different. More materials are given in the form of grammar, vocabulary, translations, language theory, etc. (the table. 3).

The obtained data gained from the field observations shows the results which close to obtained data of document, especially relates to English teaching and learning activities carried out by lecturers, trainers and caregivers. In the teaching curriculum, researcher find classical learning activities with an average number of students 60-90 students in one class. The lecturer explains the theories related to English grammar and students listened to learning activities. Considering that English lesson is given at first semester with a sufficient number of students, making teaching English becomes one-way learning activities. Lecturer and trainer become more active than students. It means students became passive learners.

The field observation results show the lack of facilities supports and infrastructure in English teaching and learning activities. The classroom's size is $10 \times 8$ meters, its old building and the students who joined in this room approximately 60-80 students, limited air ventilation, dark tinted windows, short ceiling to the floor, minimal lighting and the absence of air conditioning, making the classroom feel dark, narrow, hot and cramped. The condition of the room is hotter during the learning activities during the day, so it makes classroom become uncomfortable for English teaching and learning activities.

Besides the facilities and infrastructures, the results of field observations also show that the teaching English at teaching and training curriculum system looks similar. The material tends to be given in the form of theories and grammar concepts. Meanwhile teaching English in both curriculum is intended with different goals, training curriculum focuses more directly on English language skills (speaking, reading, writing, and listening) than grammatical theories at teaching curriculum system.

There are some ways for getting data beside document and observation. In this study, the other way for getting the data by making the interview to the informants (lecturer, and students) which have close relation to the English teaching Process. The transcription of the interview among the researcher with lecturers and students based on the facts of document findings and the results of field observations. Some students' interview results about English learning materials can be found below:

There are some students who became informants in this study. They are first semester students who get English lesson at teaching and training curriculum system. Therefore, they had learning experiences of English teaching in both curriculum system. The researcher thought it is better to choose them as informants for English learning material. As method and materials of English teaching at teaching curriculum must be different with training curriculum system, so the researcher interested in getting the information from the first 
semester students who got both of the English lesson at teaching and training curriculum system. The first informant is S1. Based on his interview, S1 said that:

.... "The material given by my lecturer is not much different from the material given by my high school teacher, about grammar. The material given is just monotonous. Even the material given by my high school teacher is better than what I am receiving now ".

While the other informant (Student 2/S2) said that:

"I had a lot of physical activities in the morning, so when I had lesson in the class I fall asleep and I think the material is not much different from the material I received at my Senior High School, It is about English grammar structure".

Another informant (S3) also said that:

"I'm confused .... when ever I heared an explanation from my English lecture, my eyes could not compromise so I got a sleep, I must be tricky to handle this situation.

Based on the above information, the English materials gave to students tend to be English grammar which similar to their previous English materials at Senior high school. This tendency made the student became boring to the English teaching process. Besides the teaching learning materials, the way of English lecturer in teaching also made the students are not interested in studying English. In this study, for making the validity of the study the researcher also makes crosscheck of students' information for getting valid information from the lecturer. The result of interview with lecturer related to the English material and teaching process that they have done. One of the informants (lecturer) is UBS. He said his statement about the material as quoted below:

"I do teach grammar with reason that whenever the student's understanding grammar they will understand how to arrange sentences."

Researchers also asked UBS informants how long they taught English, UBS said that she had taught English for more than ten years and her first teaching experience at IPDN. She was fresh graduate from private university in Bandung, she applied to be civil servant at IPDN and accepted. She was placed at IPDN language laboratory and she became English trainer. She said that she tried to apply her knowledge of teaching by teaching English grammar time by time. Even she had graduated from Magister Program for government knowledge, but she still enjoys teaching grammar rather than another topic. In this occasion, beside UBS almost all lecturers (10 out of 12 lecturers who had the first teaching experience at IPDN. The same statements were stated by other lecturers, and their tendencies of their teaching are the materials that they mastered.

The same problems related to learning English at parenting curriculum system show that English cannot be applied maximally, and it is only applied for simple discourse at English. The Facts show that educators, especially caregivers, generally do not master active English, so they only use greeting on Friday English day activities. Therefore, the given material is not exhaustive and has no significant effect for daily communication.

The same opinion also stated by the students, who said that they did not use English as the language instruction on Friday. Based on the interview, some students said that they never use English on Friday as part of Parenting curriculum system. So did the caregivers whose 
became the student's teachers also did not use Friday English activities, this is due to the limitations of caregiver's English language skills.

Beside the above explanations, the caregiver also mentioned the reasoning did not use English for communication on Friday as their limitation of their English abilities. Based on the interview, the researchers saw that the ability of caregivers in English language would be the most important aspect for implementing the teaching of English in the parenting curriculum. In addition to support all parties for practice directly, as daily communication, especially on Friday.

From the above various data presentations, it appears that various weaknesses and obstacles are associated with the implementation of English teaching in the three curriculum systems. In addition to the previous findings, the researcher also looked at the internal and external aspects possessed by IPDN through the identification at the preliminary study.

Some identification of IPDN's strength can be seen from various aspects illustrated as follows: 1). It is the only higher boarding school under the Ministry of Home Affairs; 2). It has three unique curriculum systems namely teaching, training and parenting curriculum; 3). IPDN students are best representatives' students of local areas in Indonesia who had strict selection for becoming IPDN students with comparison among 1:38; 4). Most of students have high average of intelligence. It could be proven that more than 35 percent students accepted at other famous public university before joining at IPDN.

IPDN has various opportunities that are not possessed by other higher education institutions in Indonesia. These opportunities include: 1). IPDN alumni will obtain positions as civil servants; 2). The number of IPDN alumni whose had important positions in regional and central government; 3). IPDN graduates did not only work at the Ministry of Home Affairs, but they also worked at other Ministries; 4). The chance for getting scholarship for alumni to continue their master and doctoral degree as all the IPDN alumni has been Civil servants.

Meanwhile the threats for IPDN in processing their educational activities include: 1). The Permission to extend the study program will expire. The effect of failure in the process of extension will cause the existence of IPDN can be considered illegal as IPDN does not have a study program permit; 2). Whenever IPDN did not have study program permit, it will cause the IPDN alumni cannot continue their education for further degree; 3 ). The last threats is Industrial Revolution Era 4.0 will change the paradigm of teaching, learning and other aspects.

\section{Discussion}

From the above various data findings appear that the tendencies of teaching English at IPDN have characteristics, such as: focus on teaching grammar, the lecturer centered, the middle and final examinations tend to be vocabulary test and translation. In other words, the method of English teaching at IPDN tends to be classical. The characteristics of classical approach have similarities with various characteristics of classical English teaching as proposed by Brown (2005), that the Classical approach focuses on grammar, drill of English vocabulary and conjunctions, text's translations, and writing exercises. A similar opinion was also expressed by Murcia (1979: 3) about the characteristics of classical learning, such as:

First characteristic is the English lesson taught in bahasa, and the English language is used with little active in the English learning process at class; Second, the Teaching English vocabulary is focused in the form abandoned words; Third, the Teaching English focused in English structure 
and pattern of English; Fourth, The English teaching grammar explain the rules and way for creating and making English sentence by formatting English word together in sentence. The English teaching grammar is also focused in the form of creating inflection of words for creating sentences; Fifth, Teaching reading focused on simple English texts; Sixth, teaching reading skill concentrated on content of texts that are processed for analysis of English grammar; Seventh,teaching translation is only concentrated the examination of elicit the sentence from target language to mother tongue or vice versa; last few attention of teaching English pronounciation.

This traditional approach will give a less effects on teaching and learning English that gives chance for students to make real English communication. Students are only directed to memorize sentence patterns without being able to implement real communication. So, this approach will make students become passive learners, as faced by most of Indonesian students in communicating English today. The phenomenon of Indonesia students who learn the English structure rather than English as language function since the elementary school to senior high school makes them to be passive learners of English as Foreign language.

This approach only makes the lecturer as the only source at English teaching learning process so the chance for student to participate directly is limited and they did not involve in learning activities. According to Richard \& Rodgers (1986: 4), the classical method will give effects such as:

"it also practically does little to strengthen the communicative capacity of a student in the language. Thousands of school learners recall it with distate, for whom global learning meant a frustrating experience of memorizing endless lists of unusable grammar rules and vocabulary, and trying to build accurate translations of stilted or literary prose.

Various research findings show that thousands of students learn foreign languages by memorizing vocabulary, grammar and translating less encouraging students in communication skills. This shows that classical methods do not contribute to improve students' communication skills. This method tends to be boring and tedious for students, because it only emphasizes memorizing vocabulary, sentence structure and is not associated with the context of language communication.

The emphasis on teaching English for grammar or form (structure / pattern) will only print students who are able to speak English in theory and not language as a communication tool. Larsen-Freeman (1986) suggests that grammar teaching should:

Grammar is one of the three dimensions of language themselves, but without a second dimension, that of meanings/semantics, these forms ar practically meaningless and a third dimension, pragmatics. In other words, grammar reminds us how to construct sentence (word order, verb and noun framework, modification of words, sentence fragment, clauses etc). Semantic tells us something about the meaning of words and strings and pragmatics tells us which one of many menaings to assign given the context of sentence.

Larsen-Freeman (1986) stated how grammar teaching should be, and various aspects for supporting the success of grammar teaching. Not only teaching sentence structure, but also teaching the meaning and context of sentence. Grammar teaching should be done with the right synergy through collaborated techniques. Therefore, the role and function of language as a real communication tool can be integrated with grammar and immersed into the context of direct communication. Likewise, vocabulary teaching is expected to blend with other material. 
Separate grammar and vocabulary teaching is chosen and used by English teachers with limited English knowledge. The teaching approach is by giving sentence structure formula makes them more comfortable. As Richard \& Rodgers (2001: 4) quoted by Brown (2005) that: "it needs few professional skills on the part of teachers. Checking grammar rules and translations is easy to develop and can be evaluated objectively.

Teaching English structure only requires a small number of teacher skills. The tests relate to grammar and translation, which are easier to be made with objective assessments. In relation with the previous statement, the document shows that only 7 (seven) of 12 (twelve) lecturers with bachelor's degree in English education (58\%) and 2 (two) of 12 (twelve) lecturers with a Masters degree of English education (16\%). Based on the interviews, data document and observation show that 11 (eleven) of 12 (twelve) existing IPDN English lecturers did not have prior teaching experience before. It makes various types of teaching English based on their preference. Based on the observation, the English lecturers whose undergraduate for their English education, and their postgraduate program were not English program or linguistic tend to teach grammar. Meanwhile for English lectures whose experiences for continuing her Magister at English Department or Linguistics tend to be more creative for giving their English materials. Not only English grammar but also reading text which focused on government. The other lecturers whose open minded and have high curiosity in developing their English teaching program, they also asked the other English lecturers for getting and adopting and discussing the English teaching materials. Therefore, they can develop their teaching concepts.

In other words, the lecturers have their first experience of teaching English at IPDN. It becomes the reason than the IPDN lecturer tendencies in English teaching is grammar.

The result of interview shows that the lecturer's tendencies rise as the English language teachers follow the role models of their predecessor instructors. From the available data document, most of the IPDN English language lecturers are not graduated from famous public university who produce prospective teachers. Indirectly, it has more or less impact on their teaching competence. In relation with the previous educational lecturer competences of English depend on the quality of learning process, that are not separable from the opinions of (Sanders \& Horn, 1994; Sanders \& Rivers, 1996; Wright, Horn, \& Sanders, 1997 that quoted by Darling-Hammond (2006: 19) as follows :

"..... a teacher of a child will make a greater difference to his or her educational performance than any other variables in the classroom. Studies using data on value-added student achievement found that student achievement gains are far more affected by the allocated teacher of a student than variables like class size and composition.

Essentially, the way of teachers teaching will affect how students learn. Various assumptions and research findings prove that the influence of teacher ability is very closely related to the success of students more dominant than other variables. The results of field observations and document study related to the strengths indicate that students with more ability become one of IPDN strengths. Data is based on IPDN entry selections which are quite strict. The latest data on IPDN selection in 2018 shows the number of official IPDN registrants as many as 46.062 . Meanwhile the number of formations available is 2000 students. The Comparison of the number of registrants is 1: 23 (bkn.go.id). In other word the acceptance selection stage is quite strict. Besides the strict entrance selection, the data also show that the average, $35 \%$ of each IPDN class had followed the higher education before at public famous university in Indonesia. 
Meanwhile the exist of various strengths and opportunities can be synthesized and they will become best strategies for finding the right concepts of teaching-learning English at IPDN. Utilizing the available strengths and opportunities may enhance the standard of teaching and learning English at IPDN.

Researcher tried to present the IPDN's strengths such as: 1). The only one higher boarding school which stands under the Ministry of Home Affairs; 2). IPDN has three unique curriculum systems namely teaching, training and parenting curriculum; 3). IPDN students are representative of the best students from each local government in Indonesia. They had passed through a strict selection for becoming IPDN students (1:23); 4). The ability of IPDN students are higher than average students in Indonesia, it can be proven that 35\% IPDN students have attended lectures at well-known public university in Indonesia.

The research also presents the identification of the opportunities belong to IPDN, such as: 1). Alumni of IPDN are civil servants; 2). Some IPDN's alumni have important and strategic position in both the local and central government; 3). IPDN Alumni work in some central ministries besides the Ministry of Home Affairs; 4). A great opportunity for IPDN alumni to get scholarship and continue their continuous education at the Masters and Doctoral degree in Indonesia or other countries as the requirement they must have already as civil servants.

The IPDN strengths and opportunities are synthesized through needs analysis will be an alternative strategy that can be used to develop English language teaching at IPDN. This Strengths and Opportunities can be described as SO strategy that will be the basis for needs analysis. Analysis (Need Assessment) is a process that educational needs become a priority matter or the process by which educational needs are defined and set priorities (McNeil, 2006).

Need analysis has functions for determining the factors and aspects that are needed in improving the quality of learning in the class. According to Wahyono \& Puspitasari (2015) The effective needs analysis is very important for analysts and others (teachers, staff, students) involved in carrying out the needs analysis. Need analysis will be used to determine the planning of the learning design that will be prepared and used at IPDN. The learning design will be one step for solving various English teaching learning at IPDN. As IPDN has some strengths, and opportunities that can be managed to overcome the weaknesses and threats of IPDN.

The combination of strengths and opportunities belong to IPDN, can be illustrated in the following chart:

The IPDN Strengths are:

1. The only one higher boarding school in Indonesia under MOHA;

2. IPDN has three curriculum systems;

3. All the IPDN students are representative of the best student at each local government in Indonesia;

4. The IPDN students have high intelligence. 


\section{The IPDN Opportunities are:}

1. IPDN alumni become Civil Servants;

2. Some IPDN alumni have important position in Local and central Government;

3. There are some alumni who work outside MOHA (Other ministries in Indonesia);

4. The IPDN alumni have chance for getting scholarship for continuing their study at Magister and Doctoral degree.

\section{The SO Strategies are:}

1. IPDN English Teaching is collaborative ways among IPDN personnels (students, lecturers, trainers, fellows and IPDN staffs);

2. English teaching focuses on reading skills;

3. IPDN teaching reading focuses on government ESP (English for Specific Purposes).

Based on the above mapping, the strategy that will be used is to utilize the strengths and opportunities to make strategies for solving the English teaching problems at IPDN. The strengths related to the ability of students whose have high potencies and they also live in the same dormitory, it can be synthesized to be used as a basic foundation for choosing the best strategies for solving the problems. This best strategy combined with collaboration concept. It means that the potency of the students whose live in the same dormitory can collaborate for studying English together by giving the chance for clever students to assist the slow learner students. This collaboration can be created and modified as suitable as the IPDN condition of learning. These combination between the competence of the students which support with the place they are living will give the possibilities to develop their English learning process collaboratively. As the collaboration will be easy to do when most of the students live in the same place for 24 hours.

Besides the similar place of the IPDN students, the students' competency aspects are chosen for developing the collaborative strategies. It can be used together as collaboration becomes a bridge and a way for individuals to improve their knowledge compared to working individually. This is in line with the opinion of Vygotsky (1978), related to Collaborative learning. Vygotsky suggests that students can perform their high intellectual knowledge when they asked to work collaboratively rather than individually.

Collaborative learning is interpreted as "the learning approach that designed by the teacher to the student's activities in small or pairs groups work for reaching the target or goal of learning" (Nunan, 1992). It means that the teacher modified and designed the learning activities that is described as learning design activities which carried out by the students in pairs or small groups. So the activities of the students will be the focus in developing the students' knowledge.

Collaborative learning is used to minimizing conventional learning activities. Conventional learning has a tendency to be described by Sato (2012) as follows:

Conventional learning is only carried out the textbooks, the teacher asks and students answer. The main activity for students is only listening the given explanation of the teacher carefully while sitting on a bench sweetly. In the conventional way there is only a monologue dialogue between teacher and student. The students are likely emphty tin who will accept everything. It will be considered good if students can understand the materials on their own without helping others. There isn't interdependency among the students in the class. 
While collaborative learning activities present various things that can make students learn together actively. In collaborative learning there are interactions between students and students, students and teachers, as well as the interactions made among the students in order to achieve the stated learning goals.

According to Matthews (1996: 10) the philosophy which underlying the collaborative learning concept is:

Collaborative learning arises when students and teachers work together to create knowledge ...... it's a pedagogy that's focused around the idea that people make sense together and the process enriches and enhances it.

Based on the above underlying philosophy, the collaborative learning arises when students and group members work together to gain knowledge. Besides the collaborative approach, the problems of conventional learning in the form of grammar have been solved by offering other concepts of teaching English at IPDN which developed based on student's needs. The researcher offered teaching that focuses on teaching Reading. The given reading materials are also more specified through the on given English material in the form of English For Specific Purpose. ESP is as one of the language learning programs based on content (content based).

ESP of Government is offered and directed in the formation of students' specialization (their knowledge are relevant to the student's disciplines). It is possible because ESP with all its specialties will be able to support, equip, as well as improve the student's skills and knowledges of English of government. IPDN Students is expected to learn English not only language as a communication tool, but also the mastery of Government content knowledge.

The development of the government ESP learning model is expected to give new concept and uniqueness of IPDN alumni to the objectives of the IPDN vision and mission. Considering that IPDN focuses its education on government scientific background, researchers offer ESP reading materials focusing on Government science as a strategy offered in learning English at IPDN.

It is in line with Johns \& Price-Machado's (2001) statement that ESP as a form of language teaching was designed and planned through a special learning system. The design is based on the needs and the identification of language users and background of socio-cultural conditions of learners who used that language. Meanwhile, Johnson \& Johnson (1999) added his argument about ESP, that:

.... language services tailored for groups or learners with specific interests and specifically identified needs. ESP as a recognizable practice within the wider professional context of English language teaching, with implication both for the design of syllabuses and materials and for the definition of research areas.

It has some implications for designing syllabus and material as being the one specific thing in research scope. So the nature of ESP is a concept of English language instruction program based on needs analysis of the participant and the material should be provided as suitable as the needs and background of the participants. ESP is also an important approach of teaching English at this era.

Researcher offers three alternative strategies that consider to be the steps for strengthening English teaching concepts at IPDN. The impacts of strengths and opportunities, especially for 
the IPDN students and alumni will be acquired maximally. Researcher see the weight of each strength and opportunity to be one thing that can be synergized. Therefore, the finding strategy can be used to overcome IPDN English learning problems and also finding design of IPDN English learning concept that is appropriate for situation, conditions and needs of IPDN students.

The strength of IPDN students as the best representative students of each local governments in Indonesia and they live in the same dormitory at IPDN are the strength that must always be considered. Dormitory aspects and their level of intelligence become the strengths that can be synergized with the opportunities they have in the form of positions to become ASN after they graduate from IPDN. It also the opportunities for continuing their study for Magister and Doctoral programs by getting the scholarships. This is big chance for the IPDN alumni to get scholarships as all IPDN alumni are civil servants. Another benefit for IPDN alumni is the IPDN alumni can get the strength of IPDN alumni network who have important position in all local government in Indonesia.

\section{Conclusion}

Need Analysis is a step for finding the learning strategies based on the strengths, opportunities, weaknesses belong to IPDN. Need Analysis can be used to solve English teaching-learning problems at IPDN. Based on the need analysis, it can be offered some strategies in teaching learning English at IPDN such as: 1). Teaching English at IPDN can be created in the form of collaborative English teaching among the IPDN personnel (students, lecturers, staff, etc.); 2). English teaching focuses on reading skills which combined with the English for Specific Purpose as IPDN has core knowledge in government; 3). Teachinglearning English can be focused on Parenting System Curriculum.

\section{Acknowledgment}

N/A

\section{References}

Brown, H. D. (2005). Principles of Language Learning and Teaching, (5th Ed). White Plains, MY: Pearson Education.

Creswell, J. W. (2009). Research Design: Qualitative, Quantitative, and Mixed-Method Approaches. SAGE Publications, Inc

Darling-Hammond, L. (2006). Powerful Teacher Education: Lessons from Exemplary Programs. San Francisco: John Wiley and Sons, Inc.

Heigham, J., \& Croker, R. A. (Eds.). (2009). Qualitative Research in Applied Linguistics. https://doi.org/10.1057/9780230239517

Johnson, K. \& Johnson, H. (1999). The Encyclopedic Dictionary of Applied Linguistics: A Handbook for Language Teaching. Oxford: Wiley-Blackwell.

Larsen-Freeman, D. (1986). Techniques and Principles in Language Teaching. Oxford: Oxford University Press

Johns, A. M., \& Price-Machado, D. (2001). English for specific purposes: Tailoring courses to student needs-and to the outside world. Teaching English as a second or foreign language, 3, 43-54.

McNeil, J. D. (2006). Contemporary Curriculum: In Thought and Action. John Wiley \& Sons, Inc 
Nunan, D. (1992). Collaborative Language Learning and Teaching. Cambridge: Cambridge University Press

Sato, M. (2012). Bagaimana Mengembangkan Guru Yang Profesional (Lesson Study untuk Peningkatan Profesionalisme Guru). Paper Presented in "Exchange of Experiences on Best Practices of Lesson Study".

Wahyono, E., \& Puspitasari, D. (2015). Students' Need Analysis of English Reading Skills for Academic Purposes. International Conference on Teacher Training and Education. Sebelas Maret University, Indonesia. 